\title{
The Concept of Black Bile and Its Importance in Maintenance of Health
}

\author{
Syeda Kharshiya Saher ${ }^{1}$, Mohd. Zulkifle ${ }^{2}$, Wasim Ahmad ${ }^{3}$, Tariq Nadeem Khan ${ }^{4}$
}

${ }^{1}$ Lecturer, Dept. of Mahiyatul Amraz (Pathology), National Institute of Unani Medicine, Bangalore.

${ }^{2}$ Professor and HoD, Department of Kulliyate Tib, National Institute of Unani Medicine, Bangalore.

${ }^{3}$ Assistant Professor, Dept. of Kulliyate Tib, National Institute of Unani Medicine, Bangalore.

${ }^{4}$ Assistant Professor, Dept. of Kulliyate Tib, National Institute of Unani Medicine, Bangalore.

Corresponding Author: Syeda Kharshiya Saher

\begin{abstract}
Unani system of medicine is known for its potential since ancient times. Elite Unani philosophers are credited for proposing consolidated theories and unleashing medical science from the domain of deities and demons. They have set the goal of medicine as prevention as well as cure of disease. Both the health and the disease are described in its own way in respect of functions. Unani philosophers contemplated that human body is composed of three basic components; solid (body organs), liquid (humours), gaseous (pneuma). The liquid substances of the body are collectively called as Akhlāt (humours). Every humour serves some specific and general functions. Basically, these are approximate principle for nutrition of organs. Black bile is one among the humours responsible for the health and the disease in the body. A right proportion of black bile keeps the body healthy, but disproportion of it causes deadly diseases. It is a fact that everything in the body is directly, or indirectly related with the four humours. In present study, a comprehensive explanation of black bile is given. Much emphasis is given on the genesis of normal and abnormal black bile. All factors responsible for alteration in black bile are enumerated thoroughly in the study. It is believed that the present work would help the reader in better understanding of the concept of black bile and their effect on the human health.

Methodology: Relevant literary material is collected from classical books of Unani system of medicine. Present work is an attempt to analyse and systematize collected relevant literary information regarding the concept of black bile and their effect on the human health.

Interpretation and conclusion: From the contents of literature; it is clear that black bile is the sediment of normal blood. It is the last to arise and receives the coarse, most meagre share of nutrients and has a retentive virtue, a cooling, drying, astringing, precipitating, condensing, solidifying effect on the metabolism necessary for building the bones, teeth and all dense, solid structures of the body. The black bile is an essential humour that keeps the body healthy. Therefore; an optimal level of black bile plays an important role in maintenance of health as other three humours. An imbalance in quality and quantity of black bile is responsible for the diseases.
\end{abstract}

Key words: Akhlāt Arba'a (humours); Sawdā' (black bile); health; disease.

\section{INTRODUCTION}

The human body is composed of three basic components; solid (body organs), liquid (humours), gaseous (pneuma). The liquid substances of the body are collectively called as Akhlāt (humours). Biosynthesis of humours is attributed to the digestive tract and liver. All the humours are synthesized from Istiḥāla Awwal (first metabolism) of food. Based on colour, Hippocrates classified body fluids into four (4) types viz; Dam (blood), Balgham (phlegm), Șafrā' (bile), and Sawdā' (black bile). The black bile is one of the four 
essential humours in the body. The right proportion and purity of humours are essential for maintenance of health. The main functions attributed to the humours are hemodynamic, nutritive (vegetative), excitatory, inhibitory, and transport, or carrier etc ${ }^{(1)}$. Throughout Unani text all humoral pertinent are described in the context of two attributes i.e. quality and quantity. The complete basis of health is the right proportion and specific equilibrium of Akhlāt (humour) according to quality and quantity. They impart considerable stability and balance to the inherent temperament of the body and organs with which they come in contact. Each and every humour performs its specific function and has some effect on body which is responsible for maintenance of good health. Blood is the most beneficial as well as abundant humour in the body ${ }^{(2)}$, whereas black bile is the least conducive humour in the body, even though it has some specific functions to perform. Therefore; optimal level of black bile plays an important role in maintenance of health as other three humours. A person's psychological disposition is the direct result of the proportions of the four humours in the body. Both the health and disease are described in its own way in respect of functions. Diseases are classified distinctly into three categories viz. temperamental, structural and of integrity ${ }^{(3)}$. There is a distinct category of diseases, which is associated with causative morbid matter. This category belongs to major category of temperamental diseases, which is based on humoral theory of Hippocrates. This theory emphasizes the occurrence of disease because of imbalance of the specific fluid, derived from the diet. Hippocrates proposed four types of body fluids responsible for health and disease, and since then humoral diseases have an ample description in Unani literature. Every humour serves some specific and general functions. Basically, these are approximate principle for nutrition of the organs. Every humour is attributed with specific qualities. It is considered normal and health imparting till it is within the normal (physiological) limits of its qualities and quantity. In the human body, four humours are in a definite proportion, which is responsible for individual health ${ }^{(4)}$. Any deviation results in disease, which maybe because of qualitative and quantitative deviations ${ }^{(4)}$. Many diseases of various organs and systems are also attributed to the black bile.

\section{The Galenic Concept of Black Bile}

The way humoral theory was used in ancient medicine, is of paramount importance for the importance of black bile, as a substance that can explain the cause of health and disease in the body. In Unani literature, almost all philosophers have described black bile in their treatises. Among them the Hippocratic "On the Nature of Man" is the very first treatise to describe about black bile. In this treatise a substance named black bile, which is associated with autumn and a particular stage in person's life i.e. old age ${ }^{(5)}$. In this way, black bile is raised to be on equal term to blood, phlegm and yellow bile. All of which have a clear provenance as a fundamental substance in the development of medical theories. Black bile is one among the humours responsible for the health and the disease in the body. In Galen's writings, we find the following description in 'On the faculties'- "Next, two residues produced by the way of the change of this, the one being lighter and air like, and the other being heavier and earth like" (6). In my opinion, the one being lighter is yellow bile and 'heavy, and earth-like' is black bile which is associated with element earth. Galen in his treatise "On black bile" described both terms melancholic humour, and black bile, as being like the 'lees in wine'. He also used a more direct characterisation of black bile relative to blood and called black bile the 'lees of blood', the same thing is written in "On Crises" and in his commentary on "Aphorism". The description of black bile as a solid within other fluids is emphasised by Galen in another work, in "On Mixture", he stated that "Of humours the most useful 
and particular is blood. Black bile is a kind of sediment and mud of this (blood); it is therefore colder and thicker than blood". Here Galen described black bile as a type of 'sediment' and 'mud' of blood. This is a distinctive character of black bile relative to blood and is not found applied to the other two humours, phlegm and yellow bile in any of Galen's writing. So, sediment and mud found in blood is reserved for black bile. Therefore, Galen has gone beyond the simple cold, dry and sticky substance found in the Hippocratic "On the Nature of Man" to create a broader description of black bile in terms of comparable common organic substances, such as 'lees', 'sediment' and 'mud'. These are the types of description of black bile, which are found in a range of sources beyond the content of "On the Nature of Man" (5).

Therefore, we can say that the black bile should be considered as being the lees of blood that means when we look at composite blood, the part that is heavy, which resembles the lees is in fact the black bile ${ }^{(6)}$

Description of Black bile is found in many other treatises in the "Hippocratic Corpus" (7). For example, in "On places in Man" there is a following statement about wounds of the body. "Mortal wounds; if it is any kind of a severe one and besides the wounded person vomits black bile, he dies" (9). In other Hippocratic texts, we find that black bile is associated with different types of diseases. In "Aphorism" dysentery that begins with black bile is reported to result in death. And in "On Diseases I", Black bile is said to be the cause of paralysis ${ }^{(8)}$. There are many other examples in treatise such as "Aphorism, Epidemics I-IV, Regimen in Acute diseases, On Internal Affections, On Affections, On Diseases I-III and On Diseases of Women II" (7). In the above treatises, no doubt the physicians have mentioned black bile but it is an abnormal form of black bile which is responsible for diseased conditions. Therefore, Galen attempts to explain how black bile can be both an essential humour that keeps the body healthy, but also is the cause of deadly diseases.

Some people are naturally melancholic under the influence of related temperament, while others acquire it later. Black bile becomes the key word not only of the humoral theory, but of philosophy, astrology etc. Galen characterized black bile as being sharp and sour in flavour, cold and dry in quality and is associated with the cosmic element earth, the spleen in the body, the season of autumn, the mature stage of life, and quartan fever ${ }^{(8)}$.

\section{Opinions of Unani physicians on properties of the black bile:}

$>$ According to Avicenna, Black bile is the fourth humour and is of two types; one is Sawdà' Tabi' ' $\bar{l}$ (normal black bile) $(4,11,12)$ which is the sediment of normal blood. Its taste is midway between sweetness and astringent. Avicenna termed it as Sufl or Ikrud dam (residue / sediment) ${ }^{11}$ another is Sawdā' Ghayr Tabi ${ }^{`} i$ (altered black bile) ${ }^{(4,11,12)}$.

$>$ According to Haly Abbas, the colour of black bile is black, its taste is a combination of sweet and sour ${ }^{(12)}$.

$>$ According to Ibn Hubl the colour of natural black bile is reddish black ${ }^{18}$. Its temperament is cold and dry $(2,3,4,11,12)$ and consistency is thick ${ }^{(2,3,4,11,12)}$.

$>$ Ibn Nafees says that "The position of Black bile is next to yellow bile. Black bile is inferior most amongst the humour. However, it does not mean that it has no merits; it has also some functions to serve in the body" (2).

\section{Synthesis and course of black bile}

Humours including black bile are synthesized from the food we consume. As per Unani concept, the whole process of digestion is divided into four phases ${ }^{(11)}$. The first phase i.e. gastric phase occurs in stomach, and intestine whereas the second phase takes place into the liver known as hepatic phase ${ }^{(11)}$. In this phase humours are formed. A third phase in the vessels and the 
fourth one takes place when the humours enter the organ and tissue ${ }^{(12)}$.

The diluted portion of chyle obtained from gastric phase enters the liver through the mesenteric vessels and the portal vein sequentially ${ }^{(3)}$. Then it gets distributed throughout the liver in a network with small, hairy branches (13). Being distributed into the whole liver, the chyle is exposed to the digestive power of liver. Here, Tabakh (concoction) of chyle takes place. Various products and by products are formed during this process namely, foamy substance and a sort of precipitate are formed which are yellow bile and black bile respectively (11). The partially cooked portion is phlegm and the remaining mature substance is blood ${ }^{(11)}$.

After being formed, it divides into two portions, one of which enters the blood, and the other goes to the spleen. The portion which enters into the blood sub serves two purposes.

$>$ It takes part in the nourishment of those organs which possesses cold and dry temperament like bones, hairs, nails etc $(2,3,11,12)$

$>$ It also activates blood and make it strong and active ${ }^{(14)}$.

The portion which passes to the spleen such as no longer of use to the blood. Its primary use regards the body as a whole, it clears the body of so much effete matter ${ }^{(11)}$. It uses in regards to one special organ is that it supplies nutrition to the spleen. Its secondary use is that by travelling to the fundus of stomach, which makes the stomach strong, firm and active. Its bitterness irritates the fundus of the stomach and sets up a sense of hunger and so, arouse the appetite ${ }^{(13)}$.

Therefore, black bile has got a retentive virtue, a cooling, drying, astringing, precipitating, condensing, solidifying effect on the metabolism necessary for building the bones, teeth and all dense, solid structures of the body. Black bile also awakens the stomach and appetite and enables the digestive organs to hold on to their contents long enough to process them properly. Systematically, melancholic residue in the blood stream thickens the blood, enabling it to clot. Black bile is the last to arise and receives the coarse, most meagre share of nutrients. It is the least plentiful ${ }^{(2)}$, only a slight part of it enters the circulation.

\section{Types of black bile} of black bile ${ }^{(8)}$

Galen explained, two distinct types

1) Sawdā' $\operatorname{Tabi}^{\prime} \bar{l}$ (normal black bile): It is the sediment of normal blood, cold and dry in temperament, it is one of the four humours, can only cause the harm in large quantities ${ }^{(8)}$.

2) Sawdā' Ghayr Tabì' $\bar{\imath}$ (abnormal black bile): which is produced by Ihtirāq (action of excess heat) of the Sawda' $\operatorname{Tabl}^{-} \mathfrak{l}^{-(2,8)}$.

\section{Altered forms of black bile}

Altered black bile is produced when any kind of humour, including black bile itself becomes Muhtariq (burnt out) ${ }^{(2)}$. In other words, we can say that the altered forms of black bile are the result of action of excess heat on any humour including black bile itself. This kind of black bile doesn't serve the physiological functions in the body like that of normal black bile ${ }^{(11,12)}$. The word 'Ihtirāq' is very commonly used by the Greek physicians. This term carries very vast meaning. Here Ihtirāq (action of excess heat) stands for abnormal change, in which metabolic changes go abnormally and against the nature of the body. Which results in the production of such harmful substances which are detrimental for health (15)

Ibn nafis in kulliyate Nafisi, classified four kinds of altered black bile on the basis of Ihtirāq (combustion) of substrate $^{(2)}$.

Sawdā' Damvi (Sanguineous Atrabile) is formed as a result of action of excess heat on the blood, it is least morbid form and sweet and salty in taste ${ }^{(2)}$.

\section{$>$ Sawdā, Balghami (Phlegmatic} Atrabile) is formed as a result of the 
action of excess heat on the phlegm, its taste is salty. It is the least toxic form, because it contains moisture in it, so delays the process of action of excess heat (combustion). The diseases caused by Phlegmatic atrabile are of bad prognosis ${ }^{(2)}$.

$>$ Sawdā' Șafrā'wi (Bilious Atrabile) is formed as a result of action of excess heat on Khilt Safrā', it is most toxic form and bitter in taste ${ }^{(2,4)}$.

\section{$>$ Sawdā' Sawdā'wi (Melancholic} Atrabile) is derived from the action of excess heat on black bile itself. If the black bile is more watery, attenuated form, the resultant product is extremely sour like vinegar ${ }^{(4,11,12)}$. On being dropped to ground it immediately produces froth and gives a foul smell ${ }^{(2)}$. When the black bile is thicker and denser, the resultant product is bitter and astringent rather than acrid ${ }^{(4,11,12)}$. The variety formed from the thinner black bile is more morbid than the variety derived from thicker black bile ${ }^{(2)}$. Due to thinness, this kind of black bile has more penetrability than the other one; however, it can be cured easily as compare to the variety formed from thicker black bile ${ }^{(2)}$.

Avicenna in "Canon of Medicine" stated that "The altered black bile is not obtained by the way of precipitation and sedimentation, but it obtained from the way of ashy property and Ihtirāq ${ }^{(14)}$. It is because when the moist things blend with earthy ones, the earthy parts are separated in two ways. One is by the way of precipitation, an example of this being normal black bile in the blood ${ }^{(11)}$. Another is by the way of Ihtirāq (combustion) so that the rarefied portion is dispersed and the denser portion remains, an example of this is Sawdā' Ghayr Tabī' $\bar{\imath}$ (altered black bile) (11). Actually, a precipitation is obtained merely from the blood whereas, like oil, phlegm leaves nothing, because of its viscosity and too sticky to leave any deposit, while the thin and light, yellow bile has only a trace of earthy matter in it. Moreover, yellow bile is present in blood only in traces; it is constantly on the move, and whatever little is formed, is either burnt or quickly eliminated by the body. In case if it gets putrefied, its rarefied part gets dissolute and the denser part remains behind as abnormal black bile, as a result of Ihtirāq, not from the sedimentation" (11). Thus, the varieties of morbid black bile are three types. Among them one form is Ramad (ash) of Safrā' (yellow bile) ${ }^{(4,11)}$. When yellow bile gets burnt and the rarefied portion of it is dispersed ${ }^{(4,11)}$. The more injurious and rapid in action is Sawda ' Safrā'wi (bilious atrabile), but it is more amenable to treatment ${ }^{(2)}$. Of the remaining two varieties that one which is sourer and more harmful. Still it is amenable to treatment while it is in early stage. The third variety effervesces less on earth which adheres little to the organ and is slower in its lethal action ${ }^{(4)}$. But it is obstinate in dissolution, concoction and it is less amenable to treatment ${ }^{(11)}$. Apart from the above-mentioned types of morbid black bile, one type is such that when spleen becomes weak, and unable to adequately contains, ripens or metabolizes the Sawdā, allowing excessive amount of Sawda' to spill out into the body and produces $A m r a \bar{d}$ Sawdāwiyya (diseases of black bile) like Mālankhūliya (melancholia), Yaraqan Aswad (black jaundice) and Waram Sawdā'wi etc ${ }^{(12)}$.

\section{Factors affecting the quality and quantity of natural black bile}

- Dominance of Hārr Yābis Kayfiyāt (excessive hot and dry quality) in the liver - Excessive heat in the liver, causes excessive burning of humours (3,17). Charring or burning, as used by Avicenna is analogous to the burning of food on top of a stove when evaporation of water leaves charred material. Avicenna uses the arabic word "Ihtirāq and Harq" to describe this process. The concept of charring was described by Avicenna to explain some abnormalities such as mental problems (epilepsy, 
melancholia), some types of swellings like Waram-i- Sulb, Saratān (cancer), black urine and black faeces. According to him the charring process affects the humours and turns them into unstable waste ${ }^{(17)}$. There are causes for the charring of humour. Excessive heat causes the separation of the light part from the thick in humours. This process is also accompanied by dehydration. On, Ihtirāq, the Ajza' Latif (light / thin portion) i.e. Ajza'Nariyya (fiery substance), Ajza' Haw'iyya (airy substance) and Ajza'Ma'iyya (watery substance) present in them are dispersed and the Ajza' Kathif (dense portion) i.e. Ajza' Ardiyya (earthy substance) remains as ash ${ }^{(19)}$.

- Excessive metabolic heat generated by certain types of extreme fever like choleric fever, involving the liver can also burn and char the humour ${ }^{(3)}$.

- Dominance of Bārid Yābis Kayfiyāt in $A^{\prime} d a^{\prime} H a d m$ (17) / Dominance of coldness and dryness in digestive tract (17)

- The spleen, black bile's receptacle may be weak and feeble, and unable to adequately contain, ripen or metabolize black bile in both its normal and abnormal forms, allowing excessive amount of it to spill out into the body $(3,11,12,17)$

- Excessive cold in the body congeals and solidifies the humours ${ }^{(3)}$.

- Prolong retention of Madda (morbid matter) ${ }^{(3,20)}$.

- The existence of various long standing or often repeated diseases where by the humours reduced to ash (altered black bile) ${ }^{(13)}$.

- External factors like occupation, atmospheric air and water leads to dystemperament of black bile ${ }^{(17)}$.

- Sometimes the disturbance in temperament of Khilt-i-Sawdā' is hereditary which causes diseases like Judhām ${ }^{(17)}$.

- Dietary causes are excessive consumption of Sard Khushk Aghziyā' (cold and dry diet) or raw and astringent food like cabbage, red lentil, brinjal, dried meat, hilly and desert animal's meat etc ${ }^{(17)}$. Because Sabab Māddi (material cause) of Khilt-i-Sawdā' is concentrated part of food, excessive consumption of Sard Khushk Aghziyā' increases the production of Sawdā'.

- An unbalanced emotional state, excessive grief, loneliness etc ${ }^{(12)}$.

- Disorganized living habits including staying up too late at night, over work, excessive sexual indulgence and not drinking enough fluids ${ }^{(3)}$.

- When the black bile is plentiful, its lodges (not literally, but virtually) between the liver and stomach, as a result, the formation of blood and healthy fluids is interfered and less quantity of blood is formed ${ }^{(13)}$.

\section{Spleen- A black bile's receptacle and its role in the maintenance of health}

The Spleen is considered as receptacle for black bile, to be used as needed ${ }^{(4,11,12,17)}$. Spleen is the organ that is most strongly associated with the overall management and removal of black bile in the body. It maintains an optimal level of black bile, which is necessary for healthy state ${ }^{(4,11,12,16)}$. It stores the excessive amount of black bile, which is not needed by the blood ${ }^{(4,11,12)}$. It prevents dispersion of excessive amount of black bile in the body (12). Since only few organs in the body take nourishment from black bile, excessive black bile in the circulation leads to instability in organs which doesn't take nourishment from black bile ${ }^{(21)}$. The skin of man will become dark. The body will always suffer from Yaraqan Aswad ${ }^{(12)}$. When excessive black bile reaches the brain, will developed a condition known as Mālankhüliya. And finally, when it reaches the heart, it will kill the person ${ }^{(21)}$. In this way spleen by absorbing the excess black bile prevent forgoing disease. 


\section{CONCLUSION}

From the contents of literature; it is clear that black bile is the sediment of normal blood. It has a retentive virtue, a cooling, drying, astringing, precipitating, condensing, solidifying effect on the metabolism necessary for building the bones, teeth and all dense, solid structures of the body. Black bile also awakens the stomach and appetite and enables the digestive organs to hold on to their contents long enough to process them properly. Systematically, melancholic residue in the blood stream thickens the blood, enabling it to clot. Black bile is the last to arise and receives the coarse, most meagre share of nutrients. It is the least plentiful ${ }^{(2)}$, only a slight residue enters the general circulation, the rest is stored in the spleen, to be used as needed. Although black bile is only needed by the body in small amount, but it is a potent and essential catalyst. The black bile is an essential humour that keeps the body healthy. Therefore; an optimal level of black bile plays an important role in maintenance of health as other three humours. Morbid forms of black bile are more deleterious in their effects than the abnormal forms of other humours. Since black bile is the most effete of all the humours. Its pathologies almost always involve excess, with deficiency only a minor consideration. It is to be concluded that the abnormal forms of black bile are hotter and lighter in temperament than the normal variety and have a greater penetrating and corrosive power. An imbalance in quality and quantity of black bile is responsible for the diseases.

\section{Acknowledgement: None}

\section{Conflict of Interest: None}

\section{Source of Funding: None}

\section{REFERENCES}

1. Ahmad W, Khan TN, Zulkifle M. The Explanation and Elucidation of the concept of humours. JRUM. 2014; 3(1).
2. Nafis IB. Kulliyat-e-Nafisi (Urdu Translation by Kabiruddin HM). New Delhi: Idara Kitab-us-Shifa; 1954.

3. Ibn Sina AAHIA. Kulliyat-e-Qanoon (Urdu Translation by Kabiruddin HM). New Delhi: Aijaz Publication House; 2006.

4. Majoosi AHBA. Kamil-us-Sana'a (Urdu transl. Hkm. G.H. Kantoori). New Delhi: Idara Kitabus Shifa; 2010.

5. Galen. Hippocrates On the Nature of Man (translated by W. J. Lewis and J. A. Beach) [Internet]. Medicina Antiqua: [cited on 2017 Jun 18]. Available from: https://www.stmarysca.edu/sites/default/files/attachments/files/ On_Hippocrates.pdf

6. Brock AJ. Galen on the Natural Faculty. In The works of Hippocrates and Galen [internet]. Internet Archive. [Cited on 2019 Oct 08]. Available from: https://archive.org/details/TheWorksOfHipp ocratesAndGalen

7. Craik EM. The Hippocratic Corpus: Content and Context. Routledge; 2014 Nov 27.

8. Stewart KA. What factors influence Galen's development of a theory of black bile for his explanation of health and disease in the body? [Phd thesis]. [Devon (UK)]: University of Exeter; 2016. 40.

9. Stewart KA. Galen and the History of Black Bile: In Galen's Theory of Black Bile. Brill; 2018 Oct 11.

10. Adams F. Aphorisms. In The works of Hippocrates and Galen [internet]. Internet Archive. [Cited on 2019 Dec15]. Available from:

https://archive.org/details/TheWorksOfHipp ocratesAndGalen

11. Ibn Sina AAHIA. Alqanoon Fit Tib. (Urdu Translation by Kantoori GH). New Delhi: Idara Kitab -us- Shifa; YNM.

12. Jurjani I. Zakhira khwarizam Shahi. New Delhi: Idara Kitabus Shifa; 2010.

13. Gruner OC. The Canon of Medicine of Avicenna. New York: AMS Press;1973.

14. Shah MH. The General Principles of Avicenna's Canon of Medicine. New Delhi: Idara kitab-ul-Shifa; 2007.

15. Ahmed SI. Introduction to Al Umur Al-Tabi 'yah.1st ed reprint. New Delhi: Central Council for Research in Unani Medicine; 2009.

16. Baghdadi IH. Kitab-al-Mukhtarat Fit Tibb. Vol.1. New Delhi: CCRUM; 2004. 
17. Rushd AWI. Kitab-ul-Kulliyat. New Delhi: CCRUM; 1987.

18. Abu Asab M, Amri H, Micozzi MS. Avicenna's medicine, A new translation of the 11th-century canon with Practical Applications for integrative Health care. Toronto: Healing Arts Press Rochester;2013.

19. Jurjani IIH. The treasure of Khwarzam Shah [Internet]. World Digital Library:YNM; [cited on 2019 Jan 11] Available from : https://www.wdl.org/en/item/10608/view/1/ $88 /$

20. Sina I. Al Qanun Fil-Tib Book 1 (English translation of critical Arabic Texts). New
Delhi: Dept. of Islamic Studies Jamia Hamdard; 1983.

21. Jurjani IIH. The treasure of Khwarzam Shah [Internet]. World Digital Library:YNM; [cited on 2020 Jan 14] Available from: https://www.wdl.org/en/item/10608/view/1/ 881

How to cite this article: Saher SK, Zulkifle M, Ahmad W et.al. The concept of black bile and its importance in maintenance of health. Int $J$ Health Sci Res. 2021; 11(4): 106-113. DOI: https://doi.org/10.52403/ijhsr.20210414 